KEYSTONE SYMPOSIA: MICRORNAS AND NON-CODING RNAS AND CANCER

February $11-16,2011$

Fairmont Banff Springs · Banff, Alberta

\title{
H19/miR-675 non-coding RNA expression differentiates among cancers of the human endometrium
}

\author{
Eric J. Devor ${ }^{1}$, Jill N. DeMik ${ }^{1}$, Brandon M. Schickling ${ }^{1}$, Michael J. Goodheart ${ }^{1}$ and \\ Kimberly K. Leslie ${ }^{1}$
}

Key Words: endometrium, endometrial cancer, RNA

$\mathrm{H} 19$ is a maternally expressed noncoding RNA located at chromosome $11 \mathrm{p} 15.5$ near the reciprocally imprinted insulin-like growth factor 2 (IGF2) gene. Though the function of $\mathrm{H} 19$ is unknown, it is transcribed during embryonic development after which transcription is absent in all but a few tissues including cardiac muscle, breast, ovary, uterus, and placenta. Over the past fifteen years, however, high $\mathrm{H} 19$ expression has been seen in a number of human cancers. Recently, the 2.6kb H19 transcript was shown to be the premiRNA of miR-675 whose target mRNA is the tumor suppressor RB1.

We have carried out real-time PCR assays for $\mathrm{H} 19, m i R-675$, and RB1 transcription in seven endometrial cancer cell lines and a panel of 27 primary endometrial tumors. Results showed that $\mathrm{H} 19$ and miR-675 expression is highly correlated $(r=0.84)$ and that miR-675 and RB1 expression levels are negatively correlated $(r=-$ 0.52 ). Among the primary tumors, miR675 expression is unchanged in endometrioid tumors compared to benign endometrium (-1.3 fold) but is increased in carcinosarcomas (2.7 fold) and is highest in serous tumors (7.2 fold).

Linking $\mathrm{H} 19, \quad m i R-675$ and RB1 expression with serous tumors of the endometrium suggests that RB1 suppression may be a differentiating event in serous tumorigenesis.

${ }^{1}$ Department of Obstetrics and Gynecology, University of lowa Carver College of Medicine, lowa City, lowa 52242

This work supported in part by NIH 2CA99908-7 and the Department of Obstetrics and Gynecology Research and Development Fund.

Corresponding author: Eric J. Devor, Department of Obstetrics and Gynecology, University of lowa, 3234 MERF, 200 Hawkins Drive, lowa City, IA, 52242. Telephone( 319) 335-8212 eric-devor@uiowa.edu

This is an Open Access article distributed under the terms of the Creative Commons Attribution 3.0 Unported License (http://creativecommons.org/licenses/by/3.0), which permits unrestricted use, distribution, and reproduction in any medium, provided the original work is properly cited. 